\title{
Immigrant Entrepreneurship and Economic Adaptation: A Critical Analysis
}

\author{
Jan Brzozowski
}

\section{A B S T R A C T}

Objective: The main goal of the article is to discuss the theoretical relationship between immigrant entrepreneurship and immigrant's economic adaptation.

Research Design \& Methods: The paper reviews the theoretical and empirical literature on immigrant entrepreneurship and economic adaptation of immigrants in a host country. Then the paper develops testable propositions and a theoretical model for future empirical research on this topic.

Findings: The paper describes three main potential outcomes of immigrant economic adaptation through entrepreneurship: segmented assimilation, transnationalism and provisional business project strategy.

Implications \& Recommendations: Understanding the factors that contribute to adaptation of immigrant entrepreneurs is crucial from policy-making perspective, as immigrant entrepreneurship is increasingly promoted as a viable strategy for economic adaptation for new immigrant groups in major host countries.

Contribution \& Value Added: The theoretical relationship between immigrant entrepreneurship and economic adaptation remains underaddressed in the literature. Thus, the paper contributes to the knowledge on economic adaptation of immigrants, by proposing a model of immigrant entrepreneurship evolution and development. The model stresses interrelations between immigrant entrepreneurship and economic adaptation.

\section{Article type: conceptual paper}

Keywords: immigrant entrepreneurship; entrepreneurial development; economic adaptation

JEL codes: L26, F22

Received: 9 December $2016 \quad$ Revised: 22 January $2017 \quad$ Accepted: 15 March 2017

Suggested citation:

Brzozowski, J. (2017). Immigrant Entrepreneurship and Economic Adaptation: A Critical Analysis. Entrepreneurial Business and Economics Review, 5(2), 159-176, DOI: http://dx.doi.org/10.15678/EBER.2017.050209 


\section{INTRODUCTION}

Self-employment of immigrants is increasingly considered as an effective strategy which improves the economic situation of ethnic minorities and enables their economic integration in host country. Moreover, immigrant entrepreneurship is perceived as a way by which newcomers can contribute not only to the well-being of their ethnic community, but also to the economic development of the host country (Kushnirovich, 2015). Among biggest American enterprises listed in Fortune 500 list for 2010, 204 firms were established by immigrants, yielding the combined revenues of 4.2 trillion USD and employing more than 10 million people worldwide (Partnership for a New American Economy, 2011). But also at the lower end of the economic "food chain" there are millions of small-scale immigrant businesses which pay taxes and provide income for the entrepreneurs and their families. Therefore, most of the more important countries of intensive immigration (i.e. the US, Canada, Australia and most of the EU Member States) either adopt immigrant policies that facilitate the settlement of foreign entrepreneurs or implement integration policies aimed at encouraging immigrant self-employment (Rath \& Swagerman, 2016).

Yet, the existing empirical studies on the performance of immigrant entrepreneurs and the effects of their economic integration do not confirm only optimistic outcomes. In many cases, immigrants' economic activity is connected with marginal gains, instability of immigrant businesses and lack of economic security, long working hours and exploitation of workers belonging to the owner's family (Pécoud, 2002; Caparrós Ruiz, 2010). Moreover, in terms of economic integration outcomes, the foreign-born entrepreneurs do not surpass the achievements of salaried immigrant workers (Hjerm, 2004; Hwang, Xi $\&$ Cao, 2010). The poor performance in terms of disposable income as compared to native entrepreneurs and salaried workers is visible even in the case of second-generation immigrant entrepreneurs (Beckers \& Blumberg, 2013). Additionally, most of the research on the linkage between immigrant entrepreneurship and socio-economic integration remains purely empirical, and most of the authors rely on existing theoretical approaches developed within migration studies (e.g. ethnic enclave theory - Wilson \& Portes, 1980; blocked mobility hypothesis - Li, 1997) and studies on entrepreneurship (e.g. the concept of mixed embeddedness - Kloosterman \& Rath, 2001). In terms of theoretical models, the conceptual frameworks developed by Aldrich and Waldinger (1990), Strüder (2003) and Volery (2007) are mostly static, focusing on the explanation of the determinants of entrepreneurial behavior of immigrants and/or ethnic minorities and on the identification of the structural forces that shape these behaviors. Those theories and concepts have some explanatory power in terms of describing the origins entrepreneurial activity, but are not sufficient to predict convincingly the outcome of this activity for the process of socio-economic integration of an immigrant in host country.

Consequently, the aim of this conceptual paper is to fill the gaps in theoretical discussion on immigrant entrepreneurship by developing a theoretical model on immigrant entrepreneurship development, which identifies the main factors which influence the performance of immigrant businesses and the process of the economic adaptation of immigrant entrepreneurs in a host country. To the best knowledge of the author, in the literature on immigrant and ethnic entrepreneurship there is no theoretical framework which precisely describes the relationship between those processes. Therefore, the de- 
velopment of such a model is a most important contribution of this paper to the studies on entrepreneurship and on immigrant businesses in particular. The structure of this paper is as follows: in the next section, the author critically reviews the theoretical and empirical literature on immigrant entrepreneurship and economic adaptation of immigrants in a host country, identifying the most relevant gaps in knowledge. Then the author develops a theoretical model that allows to build testable propositions for future empirical research on the socio-economic integration of immigrants and on the immigrant business evolution. Section four concludes the paper, brings the most important policy recommendations and discusses puzzles for further research.

\section{MATERIAL AND METHODS}

In this paper the author discusses the economic impact of immigrant entrepreneurship on individual level in a host country. The author critically reviews the existing literature on immigrant and ethnic entrepreneurship and develops a theoretical model on the evolution of immigrant entrepreneurship, linking the outcomes of the business activity with the individual's strategy in terms of the economic integration. To be more precise, the investigated relationship is the effect of the business creation, maintenance and development by immigrants - on the economic adaptation of such individuals in a host country. Thus, the main aim of this theoretical model is to provide a sound conceptual framework for future research on immigrant entrepreneurship, by providing a set of research propositions that might be tested in empirical studies. In such a case, several issues deserve special attention and need to be defined in a precise manner.

First, this paper deals with the immigrant entrepreneurship, a term is often connected to ethnic and diaspora entrepreneurship (Eraydin, Tasan-Kok \& Vranken, 2010). Immigrant entrepreneurs are foreign-born persons who start business activities in a host country (Brzozowski, Cucculelli \& Surdej, 2014). Ethnic entrepreneurs use their ethnic ancestry as a brand to market their products usually by offering typical ethnic goods (e.g. halal food), or services (e.g. Ayurveda medicine). Moreover, compared to immigrant entrepreneurs, the ethnic businesses might be run by the second- and former generation of immigrants born in a host country, and sometimes they might target larger ethnic groups than just one, coming from one origin country - for instance Hispanic community in the US, or Indian community in the UK (Volery, 2007). Additionally, Zhou (2004) indicates that ethnic entrepreneurs are mutually the owners and managers of their own businesses, suggesting that such firms belong mostly to the SME sector. Finally, diaspora entrepreneurship is composed by diasporans (Elo, Harima \& Freiling, 2015) - i.e. individuals from an ethnic group (both first- and former generations born in host countries) which is dispersed from one centre (original homeland - not necessarily the home country, e.g. Punjab in India, Kurdistan in Iraq) across various geographical locations (Cohen, 1992), usually in different countries (but sometimes also various cities or regions in one country). Such a form of entrepreneurship is commonly connected to transnational activities (Elo, 2016) that span across different countries and involve diasporic communities in various places (Riddle, Hrivnak \& Nielsen, 2010), for instance Chinese trading companies in South East Asia, which can operate in Singapore, Taiwan, Vietnam and all other destinations where Chinese diaspora community is strong (Zhou \& Liu, 2015). 
Second, the paper discusses entrepreneurship, in this case, as a synonym to selfemployment, which is quite common in the literature (Langlois \& Razin, 1995). The author is aware of the terminological complexity of both concepts (Faggio \& Silva, 2012), but in the case of the economic adaptation process of an immigrant, a self-employment status is usually considered as a first step for the entrepreneurial involvement and a proxy for small business ownership (Szarucki, Brzozowski \& Stankevičienè, 2016).

Third, as in the case of many other processes in social sciences and economics in particular, the relationship of interest is of a two-way nature: entrepreneurship activity influences immigrants' economic adaptation, but also the process of immigrant's economic adaptation affects the likelihood of business creation, maintenance and development (Ohlsson, Broomé \& Bevelander, 2012; Andersson \& Hammarstedt, 2015). In this sense, the self-employment propensity rises with the time spent in the host country, as an immigrant gains human, financial, cultural and social capital and the needed experience to start a business (Caparrós Ruiz, 2010). Yet, many immigrants start their businesses from the very beginning of their entry to the host country (Brzozowski \& Pędziwiatr, 2015), often encouraged by special programs within immigration policies, which encourage the entry of immigrant entrepreneurs (Hiebert, 2008). Therefore, the paper focuses on the effects of entrepreneurship on immigrant's economic adaptation only, albeit the author recognizes that the adverse relationship also takes place.

Finally, this paper focuses on the economic adaptation, a term which is often confused with the economic integration. The latter is a more exclusive term, described as a "process by which the socioeconomic characteristics of immigrant group members resemble those of natives in host societies" (Zhou \& Liu, 2015, p. 191). Within the discussion on economic integration, the main expectation is that the immigrant economic activity should gradually converge to the "perfect model". This "perfect model" is strongly dependent on the socio-economic, institutional and cultural characteristics of the host country and might differ from the one in the country of origin of immigrant. Therefore, an immigrant might follow a successful strategy of economic adaptation in the host country but, at the same time, may fail to integrate economically as, for instance in the US, where the "successful integration entails the incorporation into the middleclass core, not the segments of the mainstream occupied by working or lower classes" (Zhou \& Liu, 2015 , p. 194). Yet, most of the integration policies and political concerns on immigrant integration focus not on the "perfect model" achievement, but rather on preventing the socio-economic marginalization of immigrants: i.e. economic inactivity, long-term unemployment, precarious or illegal forms of employment and successive immigrant exploitation. Consequently, from the policy-making perspective, it is much more viable to consider how immigrant entrepreneurship affects immigrant economic adaptation. Economic adaptation "refers to the degree to which work is obtained, is satisfying and is effective in the new culture" (Berry, 1997, pp. 13-14) and entails livelihood strategies or measures of the economic achievement of immigrant at destination (Kibria, 1994).

\section{LITERATURE REVIEW AND THEORY DEVELOPMENT}

In this section, I critically review the basic literature on immigrant economic integration and I link the theoretical and empirical findings with immigrant entrepreneurship. This allows to identify the key factors that affect immigrant entrepreneurship, 
leading to a set of forms of the economic adaptation in which the business activity of the immigrant might play a differentiated role. Additionally, I formulate a set of propositions that indicate the potential direction between these processes. Finally, all the determinants and outcomes of economic adaptation are brought together in a single theoretical model, which summarizes this section.

\section{The Role of Migrants' Personal Strategies and Motivations}

Although there is not a single theory migration which can explain all aspects of population movements in the international environment, in migration studies there is a consensus that immigrants act in a complex set of linkages, which influence their decision-making (Davis, D’Odorico, Laio \& Ridolfi, 2013). Consequently, the early neoclassical models which perceived migrants as rational economic agents, i.e. selfish individuals who act only for the sake of the private economic benefit, are not suitable to fully explain the behavior of these populations (De Haas, 2010). Migrants do not act in a social vacuum, they take into the account the interests of their "important others": mostly family members, but also friends, and even co-ethnic neighbors both in the home country, the host country and in third countries in which those people reside (Kloosterman, Van Der Leun \& Rath, 1999).

The existing theoretical models on immigrant and ethnic entrepreneurship either point out at the structural forces which drive immigrants towards self-employment or at the specific interaction between immigrant and environment in which one operates. For instance, in seminal contribution of Aldrich and Waldinger (1990), entrepreneurial actions result from the existing opportunity structures and resources, understood as the ethnic group characteristics (i.e. cultural traditions, ethnic networks etc.). Therefore, the "ethnic strategies emerge from the interaction of opportunities and group characteristics, as ethnic groups adapt to their environments" (Aldrich \& Waldinger, 1990, p. 114). This approach is somehow surprising, as it presents the ethnic entrepreneur as the object of transformation of external forces, neglecting individual aspirations ${ }^{1}$ and the role of entrepreneurs as the actors of change. In Strüder's (2003) approach, there is no place for individual entrepreneur at all, as the model analyzes the ethnic business, not the owner and founder of the firm. This is once again intriguing, as most of popular forms of immigrant entrepreneurship are rather small and medium-size businesses (Volery, 2007; Rath \& Swagerman, 2016), in which the analysis of the entrepreneur is crucial for the understanding of the firm further evolution. The individual perspective of entrepreneur is only included in the enhanced interactive model of ethnic entrepreneurship, developed by Volery (2007). The author recognizes, that individual characteristic matters for entrepreneurial actions, thus: "even people with the same nationality or from the same ethnic group have differences which affect the way they recognize and pursue opportunities" (Volery, 2007, p. 36). His understanding of personal motivations is much alike to the neoclassical approach, consequently does not taking into the account the role of "important others", which obviously affects the economic behavior of immigrant in a host country.

Developing this line of argumentation, I argue that the theoretical model of immigrant entrepreneurship should take into the account the role of migrants' families and friends, which is suggested in migration studies by the new economics of labor migration

\footnotetext{
${ }^{1}$ Aldrich and Waldinger (1990) actually tend to suggest that the ethnic entrepreneurs from the same group share the same motivations and aspirations, so there is no internal heterogeneity within the ethnic group.
} 
(De Haas, 2010). In this aspect, most economic decisions, including the entrepreneurial ones, are the result of collective decision making and of the interplay of the aspirations, dreams and personal goals of migrant and one's family located both in host and home country. Consequently, if an immigrants starts a business activity in a host country, one's entrepreneurial strategy is deeply influenced not only by the individual interest, but also by the economic interests of "important others". Let us consider three different situations of immigrant entrepreneurs, which are provided in the literature on immigrant and ethnic entrepreneurship. In a first scenario, described by the new economics of labor migration theory, a migrant is sent abroad by the entire family/household, which aims to diversify the sources of income. Upon arrival and after the business is started, a migrant is expected to contribute to the collective budget of the household located in a home country through remittances (Taylor, 1999). Moreover, at least in the context of the initial motivations, the migration itself is perceived as a temporary event, which should help in accumulating needed capital to be invested back in the home country (Coniglio \& Brzozowski, 2016). In this context, the immigrant's business development is constrained by the fact that the profits would be either continuously transferred back to the home country (to contribute to the budget of the migrant's household), or reinvested in the home country after the migration spell is resumed. Consequently, there should be no surprise that many migrants who adopt such strategy are pursuing business activities in the niches of the markets left by the native entrepreneurs, who perceive them as less attractive due to low profits, higher risk and harsh working conditions. The perspective of such migrant is much different from a native entrepreneur, as the migration is planned as a temporary event. Therefore, they accept harsher working conditions and higher risk of the business activity, as the migration strategy entails rather short- or middle-term form of entrepreneurship, rapid accumulation of capital (combined with limited consumption in host country) and yet is considered as profitable because of the income differentials between destination and home country.

The second scenario entails a situation, in which a migrant does not want to choose between a definite settlement in a host country, but on the other hand does not have any clear vision whether the return to home country should be envisaged. In such a case, the transnationalism strategy is possible. Immigrant transnationalism is a situation, in which an immigrant maintains personal, social or economic activities in both worlds: in the home and destination country (Schiller, Basch \& Blanc, 1992; Portes, Guarnizo \& Landolt, 1999; Vertovec, 2004). In this way, one's presence is manifested simultaneously in both countries. The transnational immigrant entrepreneurship in this case is manifested through a maintenance of business activities in dual locations. This kind of strategy can both be perceived as the alternative form of economic adaptation in a host country (Portes, Guarnizo \& Haller, 2002), but also as a more secure alternative: this way the potential homecoming is facilitated, as the immigrants maintains an economic foothold in a home country (Levie and Smallbone 2009). Moreover, in some instances the transnational immigrant entrepreneurs due to access to very specific and unique set of resources, both in host and home country, are able to outperform the competitors, understood as non-transnational immigrant entrepreneurs (Brzozowski, Cucculelli \& Surdej, 2014) or even native ones. 
In the third scenario, the immigrant has the intentions to stay permanently in the host country ${ }^{2}$. Consequently, the immigrant should - other things held constant - adopt a more long-term perspective in one's enterprise development. However, even in this case the entrepreneur's activities are influenced by different norms, values and expectations than the ones respected in a host country, an issue that will be considered in the next section. Moreover, in such occasions, the development of an immigrant enterprise might be connected to different outcomes in economic adaptation. The segmented assimilation theory clearly shows, that the immigrants must not follow one single path of the cultural, but also socio-economic integration, over time spent at the destination becoming much more alike to the receiving society (Portes \& Zhou, 1993). On the contrary, they might follow different directions, including social marginalization, or integration within the ethnic enclave economy, or finally experience the mainstream integration. In this contexts, also immigrant businesses can be developed into: 1) highly segmented marginal firms, operating in the niches of the market left by the locals, 2) ethnic enterprises, which operate in the ethnic enclave and serve mostly the co-ethnic population (i.e. product-integrated firms), or cater the wider clientele by offering specific ethnic goods and services (i.e. market-integrated firms), finally to 3) highly integrated mainstream businesses, which compete on equal terms with native entrepreneurs (Curci \& Mackoy, 2010). Therefore, I formulate the following proposition:

Proposition 1: Migrants' strategies have an impact on the entrepreneurship creation and further busi-ness development.

Expanding on this general proposition, it is important to consider that the businesses created by immigrants are closely connected to their migration projects, which means that those businesses can serve different purposes, where the future return and the permanent settlement at destination are the two opposite perspectives. In reality, most of the immigrant entrepreneurs "stay in the middle", drifting between those two alternatives. Therefore, there is no single, "perfect" path of the immigrant enterprise development.

\section{The Role of Cultural Differences}

Most of immigrants, when coming to the host countries bear a set of cultural values, norms and ethnic identities which might and usually do differ from the ones respected and practiced by the native population (Berry, 1997). Those cultural values influence not only the religious practices, social behavior and habitation strategies (e.g. widespread tendency to live in the ethnic districts, where the neighborhood consists mostly of people from the same ethnic background), but also affect the economic decisions of immigrant and the family in the host country.

The values and consequently the attitudes towards entrepreneurship do differ substantially across countries and nations (Basu \& Altinay, 2002). One of the important measures that shows the attitudes towards business activity is the variable "Entrepreneurship as Desirable Career Choice", included in the Global Entrepreneurship Monitor (GEM). This indicator shows what percentage of the adult (18-64) population in a given

\footnotetext{
${ }^{2}$ In all aforementioned scenarios, I consider only immigrant motivations and future plans, which can possibly change over time. Albeit this can happen with many migrants (especially in the case of temporary migration, which can easily be transformed into a more permanent one), the rich literature on that topic clearly shows that the initial motivations clearly matter for the economic decisions taken at the destination (e.g. Dustman and Mestres, 2010).
} 
country agrees with the statement that statring own business activity is the right strategy for career development. The most recent results of GEM survey for 2014 and 2015 show a great heterogeneity in the value of this indicator, ranging from extreme $95.6 \%$ in Guatemala, very high values in Brazil, Philipines and South Africa (over $70 \%$ for each country), moderate ones in the US and most of the EU member states (between 50 and 65\%), and very low values in India, Japan, Southern Korea and Finland (below 50\%, cf. GEM 2016). Therefore, in some host countries the "ideal" career path is the waged employment, while in others the businessman status (Pécoud, 2003). Moreover, as the classic research of Hofstede (2001) shows, the attitudes towards risk-taking, a crucial precondition for entrepreneurial activity, are also very heterogenous across the national cultures. Some nations are more risk takers than others. For instance, a reservation towards risk especially visible in the case of CEE nations, which is attributed mostly to a heritage of the communist system which still influences people's identities and beliefs. This risk aversion matters for the self-employment propensity: the recent study of Szarucki, Brzozowski and Stankevičienè (2016) sugests that the Polish and Romanian immigrants in Germany exhibit much smaller likelihood of becoming self-employed than in the case of other ethnic groups.

Moreover, in the case of many national cultures, the wealth of the individual might not be perceived as the ultimate life goal. For instance, the last wave (2010-2014) of World Values Survey (WVS) shows a great disparity within the nations in terms of how wealth is perceived: almost $30 \%$ of Nigerians totally agree with the statement "It is important to be rich; to have a lot of money and expensive things", while in the case of Indians this share was $18 \%$, Philipinos $-8.5 \%$ and for Poles mere $1.6 \%$, just to mention few important migrating nations (WVS, 2016). The need of acceptance or social recognition is also very important. Some national cultures are sceptical towards the wealth accumulation and people living there expect an individual to share his/her wealth with family members, even with distant relatives. Thus, solidarity with members of the same ethnic group becomes an important motivation which influences the economic activity of many immigrant groups, including for instance Lebanese (Abdelhady, 2006) or Mexican immigrants in Northern America (Vallejo \& Lee, 2009). In such a case, the immigrant entrepreneur might be expected to contribute with some share of his income in social capital building, by supporting charity and religious organizations and community events - both in the host and home country (Lindley, 2009). Such investments for the investigator who is not aware of the socio-cultural context in which immigrant entrepreneur operates, might be perceived as unproductive spending, as their impact on individual income is not significant. Yet, although less productive in pure economic sense, these social investments might be important for the entrepreneur in the long run, as they give access to other forms of capital: including social and lead to the creation, extension and enforcement of personal linkages, both business and private ones. Moreover, they might contribute to the increment of the social position of immigrant entrepreneur in the local co-ethnic community, both in the host country and in the home one (Grigolini, 2005). Additionally, we have to take into account a potentially adverse effect, which is due to the high social pressure coming from co-ethnic community: lack of such financial contribution to a given ethnic cause (e.g. to the repair of local temple, organization of local religious or ethnic festival, or contribution to some other charity goal) might lead to 
ostracism and to a social exclusion of immigrant entrepreneur. The risk of a social exclusion is a strong disciplinary mechanism in many ethnic communities (Sanders \& Nee, 1996), and the potential costs of such act might strongly (and negatively) influence the performance of the immigrant's enterprise. Consequently, it is justified to formulate the following proposition:

Proposition 2: The societies in host and home countries have diverging sets of values and expectations towards the economic adaptation, which in turn influence immigrant business activities.

It is worth to expand this general reasoning, by adding a remark that the business activities of immigrants are created, sustained and developed not only for the purpose of income maximization. Moreover, the influence of co-ethnic community in host and home countries, contrary to what is suggested in the existing literature, must not be only positive. Therefore, the obvious direction of future research on immigrant entrepreneurship is in-depth investigation of the internal, co-ethnic social norms and obligations that can inhibit and restrain the growth of such businesses.

\section{The Role of the Socio-Economic System in the Host and Home Countries}

The current literature on entrepreneurship emphasizes the role of the economic development of a country in which the businesses operate for the incidence, dynamics and in explaining the existence of different forms of entrepreneurial activities (Wennekers, Wennekers, Thurik \& Reynolds, 2005; Acs, Desai \& Hessels, 2008). Still, immigrant are the actors who bridge at least two socio-institutional environments: of the host and home countries. Migrants when adapting to a new situation in host country, are still influenced by "clichés" of the livelihood strategies from their home countries and regions. Therefore, the level of the economic development at home and the characteristics of local economy matter for the entrepreneurial model chosen in the destination by immigrant. For instance, immigrants coming from rural and conservative areas would be much more traditional and risk averse in terms of their entrepreneurial characteristics than the immigrants coming from developed cities in which the economic environment are much more innovative and competitive.

The situation becomes even more nuanced, when one realizes that these socioinstitutional environments of the home and host countries are not stable: they can, and usually they do change over time. Moreover, due to a set of interpersonal connections between immigrants and their families and friends at home, such changes do influence activities of immigrants, including the economic ones and the entrepreneurial strategies in particular. In this vein, it is important to take into the account the social networks and connections created by diaspora members. The term of diaspora stresses the dispersion of the ethnic group from one centre to various geographical locations (Cohen, 1992). Yet, the communities originated from one place, and currently located in these different destinations retain common identity and multiple (social, cultural and economic) linkages not only with the "home" or "homeland" (understood as the place of origin, but not necessarily home country, as there are nations without nation-state), but also between each other (Brubaker, 2005).

The diaspora framework offers a new perspective for investigation of immigrant entrepreneurship and its impact on the economic adaptation of immigrants. The traditional framework assumed the existence of South-North dichotomy, in which immigrants originated from usually poorer, underdeveloped countries of the Southern hemisphere. By 
settling in the developed economies of the North, they were gradually learning how the "modern" socio-economic settings differ from the "backwarded" environment in the home country, and they were consequently adjusting their business activity to fit into these new patterns. Yet, Elo clearly shows, that immigrants do not only move between developing and developed countries (Elo, 2016). As she rightly points out, the forms and directions of migration movements are in reality much more complex and multidirectional, and they occur not only from developing and emerging countries to developed, but also in an opposite direction, thus yielding 9 types of diasporan entrepreneurs: "poor-to-poor", "less poor-to-poor", "rich-to-poor", "poor-to-less poor", "less poor-toless poor", "rich-to-less poor", "poor-to-rich", "less poor-to-rich" and "rich-to-rich". In same line, Harima (2014) discusses about the "Ascending Diaspora Entrepreneurship" for those individuals who move from less developed countries to more developed ones, and "Descending Diaspora Entrepreneurship", for those who move in the opposite direction, suggesting that the incidence of this second type of entrepreneurs is also substantial and worth further investigation. These two typologies are even more useful, when the dynamics in the condition of the source and destination economies is taken into the account. The destination country can be hit by a serious economic recession, which diminish the economic opportunities for immigrant entrepreneurs and reduces the attractiveness of this environment in terms of conducting further business activities. On the other hand, the home country can also change, for instance by advancing economically from low income to lower middle income category, which in turn offers new perspectives and opportunities for future investors. In such a case, immigrant entrepreneurs might and usually do respond to changing economic environment, consequently changing their business models. One of the possible transformations of immigrant businesses in the case of the falling attractiveness of the host country and the luring economic boom at home might be the decision to move back the business to the place of origin or maintain dual economic activities at source and destination economies.

Immigrant entrepreneurs are potentially in a favorable situation when considering to move or start a business activity in their home country. Thanks to rich diaspora networks, they are able to gather information, funds, employers and know-how in a faster and more efficient way than the outsiders, namely the foreign investors. Consequently, they have country-specific cultural capital that allows to identify and exploit new opportunities more effectively than in the case of foreign entrepreneurs. The experience of such economies as China or India clearly show that diaspora investment played a pioneering role in transformation of these countries (Smart \& Hsu, 2004; Kapur, 2010). Moreover, diasporans can play a key role in the growth and internationalization processes of businesses that operate in a source country (Minto-Coy, 2016). In such a case, a diasporan entrepreneur might either start transnational business activity, form partnerships with existent firms at home or even consider return migration, to reap the benefits of this economic boom. Consequently, I formulate the following proposition:

Proposition 3: The level of the economic development at host and home countries influences immigrant entrepreneurship.

Expanding on this proposition, it is worth to consider a potentially inverted u-shape, non-linear relationship between the economic development at home country and the propensity of entrepreneurial engagement of immigrant entrepreneur, both in the em- 
pirical studies on transnational immigrant entrepreneurship and the entrepreneurial activities of the returnees. At the early stage of economic development, the lack of effective institutions and market mechanisms and poor infrastructure does not encourage entrepreneurial involvement of the diaspora entrepreneurs. Then, the intermediate levels of development offer better perspectives for such activity, as the growth potential of the home country increases and the institutional environment is more favorable for investors. Finally, as the home country becomes a highly-developed economy and the internal market becomes very competitive and saturated, the possibilities for the market entry for new players, including diaspora entrepreneurs tend to decrease.

\section{The Role of Immigrant's Family}

A very typical, yet overlooked problem in the discussion on immigrant businesses is the role of the family. As the social embeddedness theory suggests, the individual's networks and personal relationships are vital, especially when one wants to mobilize the resources to support a new economic activity, such as firm startup. Thus, family members not only provide a financial capital, but also contribute indirectly, through business ideas, advice, knowhow transfer etc. This family support comes not only from the relatives located in the neighborhood, but also from the ones who stay in the home country or other geographical locations (i.e. other countries of immigration). Still, the family reunification in the host country strongly affects the further immigrant business evolution, as the long-term commitment to permanent settlement implies the need for evaluating the existing forms of economic activity. In this sense, an immigrant entrepreneur must decide whether the existing business model is still suitable for the needs of his/her family (Bird \& Wennberg, 2016).

Moreover, most of the small immigrant businesses are also family firms (WaltonRoberts \& Hiebert, 1997), in which family members are the partners, owners, managers and employees in the enterprise. Therefore, the role of the family is usually crucial not only for the process of business creation, but also in its further development and evolution (meaning also the possible exit from entrepreneurship, cf. Bird \& Wennberg, 2016). Thus, the impact of family on the business performance should be investigated in detail. From the well-developed literature on family firms' research we know that family enterprises are not necessarily the most profitable ones, but they value the long-term goals and the sustainability of doing business over short-term gains (Block, 2010). Thus, they might offer less competitive salaries, but at the same time - more stable jobs (Bassanini, Breda, Caroli \& Rebérioux, 2013). The same can be said about many immigrant businesses. Albeit they often rely on the ethnic enclave and ethnic market, employ ethnic employees, this is not only the weakness of the firm. The employees from family in the immigrant enterprise can be less skilled and more conservative, but on the other hand more committed to a common goal, more trustworthy and hardworking. Additionally, an immigrant might take suboptimal economic decisions in terms of transactions, while choosing a client or supplier, who offers a smaller price or lower quality of goods and services, but on the other hand he/she is a member of a family (especially in non-Western world the notion of family is much broader and extends over more distant relatives, such as uncles or cousins). Therefore, such decision might be suboptimal from purely economic perspective, but profitable from the social capital perspective, because is involved with reciprocity (i.e. "favor for favor" effect). Finally, often the patriarchal relations in the immigrant family firms (WaltonRoberts \& Hiebert, 1997) lead to the exploitation of the family employees and to the inter- 
nal crises within the companies, which are dangerous both for the enterprise's and the family's internal coherence. Therefore, I formulate the following proposition:

Proposition 4: The family plays a key role in immigrant firms' creation and development.

This proposition provides some suggestions for further exploration of the role of the family on the entrepreneurial activities of immigrants. Even if the role of the family is stressed already in the literature on immigrant entrepreneurship (e.g. Mustafa \& Chen, 2010), there is an obvious deficiency of approaches that investigate the negative impact of families on the business development. In such a case, the studies on immigrant entrepreneurship should look for the factors which are already well-known in the studies on family firms, including the problems of succession and transmission of power (Surdej \& Wach, 2012) within the businesses owned by immigrants' families.

\section{The Outcome: Segmented Assimilation, Temporary Business and Transnationalism}

Based on the aforementioned factors that affect immigrant entrepreneurship and economic adaptation of immigrants in a host country, I integrate them within an unified framework (model), which brings together inputs, the intervening factors and proposes three different outcomes of an immigrant business strategy (see Figure 1). The immigrant starts a business activity in a host country using his/her skills (formal education, entrepreneurial capabilities) and experience (business and professional). At the same time, immigrant's business activity from the very beginning is influenced by personal motivations and migration strategy - both of which are the results of the internal negotiations between a migrant and his/her family (including family members residing both in the host and home country). Once the business entity is created, its development is influenced by a set of intervening factors which originate from (at least) 2 sources: the host and home country. These factors include the level of socio-economic development, and the set of socio-cultural norms and expectations towards the immigrant.

Based on these inputs and factors, immigrant entrepreneurship can evolve into three distinct strategies of economic adaptation:

- Provisional business project: in this case, the migration is perceived as an intentionally temporal one. Therefore, the business model implies the exit from entrepreneurship after the economic aim (acquisition of a specific amount of financial capital) is achieved, as immigrants intends to return to home country. In this scenario, the profits are not invested in a further development of the enterprise, but mostly transferred back to home country. In this scenario, the typical model of entrepreneurship is a micro-enterprise, and the immigrant alone is self-employed in the firm.

- Segmented assimilation: this strategy implies the permanent stay of immigrant and (usually his/her family in a host country. Consequently, the immigrant firm is either developed in order to provide a stable source of income for entire immigrant's family, or the business is closed. In the case of the business development, the immigrant enterprise fate depends on the initial outputs and the socioeconomic development of the host country, yielding at three different options: 1) highly segmented marginal firms, operating in the niches of the market left by the locals, 2) ethnic enterprises, which operate in the ethnic enclave and serve mostly the co-ethnic population (i.e. product-integrated firms), or cater the wider clien- 
tele by offering specific ethnic goods and services (i.e. market-integrated firms), finally to 3) highly integrated mainstream businesses, which compete on equal terms with native entrepreneurs (cf. Curci \& Mackoy, 2010).

- Transnationalism: a strategy which implies an economic engagement of immigrant in both locations: at home and host country. In this sense, an immigrant maintains sociocultural and economic ties with two worlds, which can be perceived as an intermediary strategy, allowing for flexible movements between segmented assimilation and provisional business project. Therefore, the immigrants keep both options "open". Yet, this strategy might also evolve into a more permanent and alternative model of economic adaptation, forming a viable alternative to the former ones. Yet, the continuity of such forms of economic adaptation and transnational immigrant business activities remains until now relatively unknown and needs much more in-depth research.

INPUTS

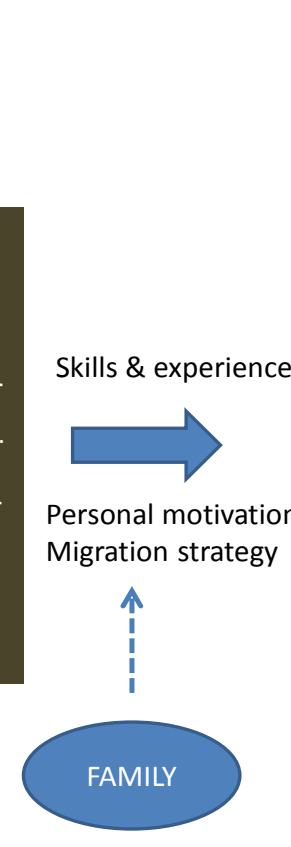

INTERVENING FACTORS

\section{Host country}

Set of norms \& expectations
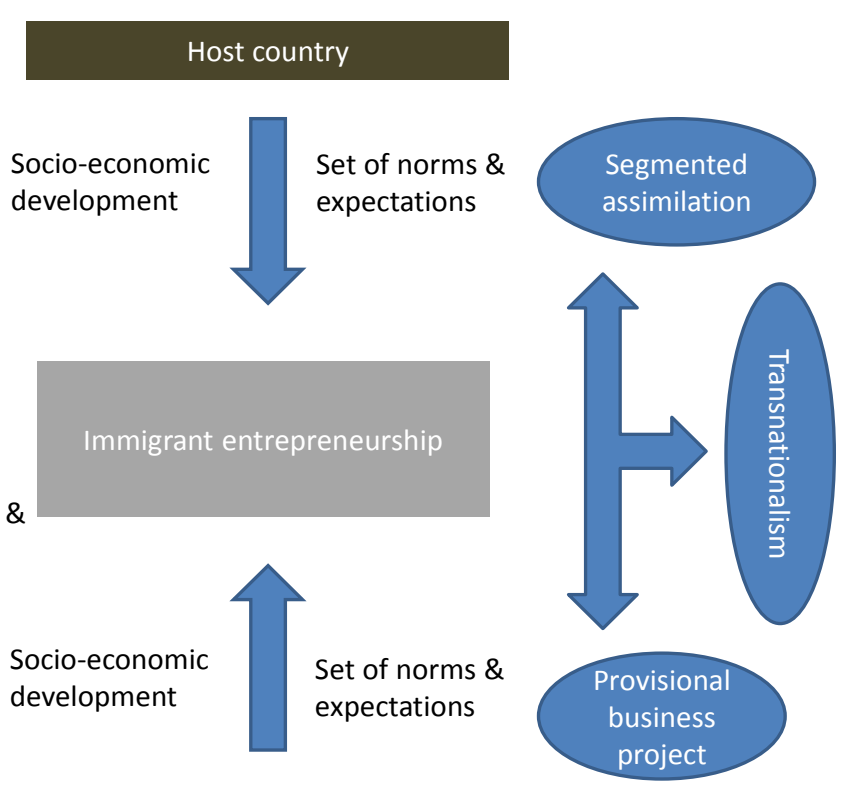

OUTCOMES

Home country

Figure 1. The theoretical framework for immigrant entrepreneurship and economic adaptation outcomes

Source: own elaboration.

\section{CONCLUSIONS}

In this paper, I developed a set of testable propositions that might be helpful in empirical analyses on the role of entrepreneurship in the process of economic adaptation of immigrants in their host countries. I am pointing out at the significance of migrants' personal strategies and motivations, the role of cultural differences between immigrant's home and home country, socio-economic system in the host and home countries, and the im- 
portance of immigrant's family in running the business project. All these factors need to be taken into account while investigating the impact of immigrant entrepreneurship on the economic conditions of immigrant in a host country. Yet, the advantage of the model is its elasticity: as the list of determinants is not exhaustive, the researchers that adopt this framework for future analyses can easily drop and add new elements.

In terms of the puzzles for further research on immigrant entrepreneurship and economic adaptation, several issues need to be addressed. First, the clear limitation of the current analysis is the emphasis on mostly positive role of the ethnic networks, resources and family ties. Yet, those factors can also have an adverse, negative effect on the immigrant firms: social pressure, family obligations and cultural norms obviously do influence an entrepreneur, but might lead to suboptimal managerial and investment decisions. Second, there is a need of deeper understanding of how the immigrant firms evolve over time, and what is the role of the social networks (including family connections, but also co-ethnic ties) in this regard. The analysis of the evolution of immigrant businesses has to take into the account the heterogenous paths and strategies adopted by immigrants and their families. In this context, it is important to remember that entrepreneurial activity usually follows a mobility of the person, and it is partly a result of the adopted migration strategy of the individual as well as his/her family. In this sense, entrepreneurial motivations and plans of the immigrants do not resemble the ones adopted by the native population. Moreover, it means that many immigrant business projects can be intentionally short-lived, and the aims of such activities is to accumulate funds at home, anticipating future return.

This remark has also some implications for empirical investigations and the methods adopted. The existent typical approaches based on case studies or on representative quantitative surveys are not helpful in explaining the evolution of immigrant enterprises. A much more promising approach is the usage of qualitative panel survey, which implies the cyclical in-depth (structured) interviews on smaller, non-randomly selected groups of respondents. Such approach combines the advantages of the panel survey (i.e. possibility to catch the dynamism of the immigrant business activity) with the benefits of in-depth interviews, which enable more flexible approach and further investigation of the new trends of immigrant economic activities.

Third, we have to take into the account the importance of former, failed business projects and their importance for current and future forms of economic activities of immigrants. The weakness of the current literature of immigrant entrepreneurship is the fact that most of empirical analyses include only "winners" or "survivors", i.e. these individuals which at least succeeded in starting an entrepreneurial activity and at the moment of investigation were still operating such businesses. Still, there are numerous individuals who either started their firms and failed, or the ones who have not even succeeding in creating a firm they wished to create. How these experiences influenced their process of economic adaptation in a host country? Have these failed business attempts made them stronger or weaker in this regard? Have they tried again to become entrepreneurs? These are only few of the research questions that need to be answered.

\section{REFERENCES}

Abdelhady, D. (2006). Beyond home/host networks: Forms of solidarity among Lebanese immigrants in a global era. Identities: Global Studies in Culture and Power, 13(3), 427-453. 
Acs, Z. J., Desai, S., \& Hessels, J. (2008). Entrepreneurship, economic development and institutions. Small Business Economics, 31(3), 219-234.

Aldrich, H. E., \& Waldinger, R. (1990). Ethnicity and entrepreneurship. Annual Review of Sociology, 16(1), 111-135.

Andersson, L., \& Hammarstedt, M. (2015). Ethnic Enclaves, Networks and Self-Employment among Middle Eastern Immigrants in Sweden. International Migration, 53(6), 27-40.

Bassanini, A., Breda, T., Caroli, E., \& Rebérioux, A., (2013). Working in family firms: paid less but more secure? Evidence from French matched employer-employee data, ILRReview, 66(2), 433-466.

Basu, A., \& Altinay, E. (2002). The interaction between culture and entrepreneurship in London's immigrant businesses. International Small Business Journal, 20(4), 371-393.

Beckers, P., \& Blumberg, B. F. (2013). Immigrant entrepreneurship on the move: a longitudinal analysis of first-and second-generation immigrant entrepreneurship in the Netherlands. Entrepreneurship \& Regional Development, 25(7-8), 654-691.

Berry, J. W. (1997). Immigration, acculturation, and adaptation. Applied Psychology, 46(1), 5-34.

Bird, M., \& Wennberg, K. (2016). Why Family Matters: The Impact of Family Resources on Immigrant Entrepreneurs' Exit from Entrepreneurship. Journal of Business Venturing, 31(6), 687-704.

Block, J. (2010). Family Management, Family Ownership, and Downsizing: Evidence From S\&P 500 Firms. Family Business Review, 23(2), 109-130.

Brubaker, R. (2005). The 'diaspora'diaspora. Ethnic and Racial Studies, 28(1), 1-19.

Brzozowski, J., Cucculelli, M., \& Surdej, A. (2014). Transnational ties and performance of immigrant entrepreneurs: The role of home-country conditions. Entrepreneurship \& Regional Development, 26(7-8), 546-573.

Brzozowski, J., \& Pędziwiatr, K. (2015). Pushed to the mainstream market: the case of immigrant entrepreneurs in Lesser Poland. In L. Faltan (Ed.), Cross-Border Migration and its Implications for the Central European Area (pp. 178-198). Bratislava: Institute for Sociology of the Slovak Academy of Sciences.

Caparrós Ruiz, A. (2010). Self-employment or paid employment as the first job: Evidence from Spain by nationality. International Journal of Social Economics, 37(12), 951-969.

Cohen, R. (1992). The diaspora of a diaspora: the case of the Caribbean. Social Science Information, 31(1), 159-169.

Coniglio, N.D., \& Brzozowski, J., (2016). Migration and Development at Home: Bitter or Sweet Return? Evidence from Poland. European Urban and Regional Studies, forthcoming, doi: $10.1177 / 0969776416681625$

Curci, R., \& Mackoy. R. (2010). Immigrant Business Enterprises: A Classification Framework Conceptualization and Test. Thunderbird International Business Review, 52(2), 107-121.

Davis, K.F., D'Odorico, P., Laio, F., \& Ridolfi, L., (2013). Global Spatio-Temporal Patterns in Human Migration: A Complex Network Perspective. PLOS ONE, 8(1), 1-8.

De Haas, H., (2010). Migration and Development: A Theoretical Perspective. International Migration Review, 44(1), 227-264.

Dustmann, C., \& Mestres, J., (2010). Remittances and temporary migration. Journal of Development Economics, 92(1), 62-70.

Elo, M. (2016). Typology of diaspora entrepreneurship: Case studies in Uzbekistan. Journal of International Entrepreneurship, 14(1), 121-155.

Elo, M., Harima, A., \& Freiling, J. (2015). To Try or Not to Try? A story of diaspora entrepreneurship. In R. Van Tulder, A. Verbeke, \& R. Drogendijk (Eds.), The Future of Global Or- 
ganizing (Progress in International Business Research, Volume 10) (pp. 283-293). Bingley: Emerald Group Publishing Limited.

Faggio, G., \& Silva, O. (2012). Does self-employment measure entrepreneurship? Evidence from Great Britain. (SERC Discussion Paper 109). London: Spatial Economics Research Centre (SERC), London School of Economics.

GEM (2016). Global Entrepreneurship Monitor - Adult Population Survey Measures, 2015. London: Global Entrepreneurship Research Association. Retrived on December 9, 2016 from: http://gemconsortium.org/data/key-indicators

Grigolini, S. (2005). When houses provide more than shelter. In L. Trager (Ed.), Migration and economy: Global and local dynamics (pp. 193-224). Lanham: AltaMira Press.

Harima, A. (2014). Network dynamics of descending diaspora entrepreneurship: Multiple case studies with Japanese entrepreneurs in emerging economies. Journal of Entrepreneurship, Management and Innovation, 4, 65-92.

Hiebert, D. (2008). Big potential, small reward? Business Class immigration to Canada. In C. Oliveira \& J. Rath (Eds.), Migrações Journal - Special Issue on Immigrant Entrepreneurship, October 2008, n. 3 (pp. 31-47). Lisbon: ACIDI.

Hjerm, M. (2004). Immigrant entrepreneurship in the Swedish welfare state. Sociology, 38(4), 739-756.

Hofstede, G.(2001). Culture's Consequences: Comparing Values, Behaviors, Institutions and Organizations across Nations (2nd ed). Thousand Oaks, CA: Sage.

Hwang, S.S., Xi, J., \& Cao, Y. (2010). The conditional relationship between English language proficiency and earnings among US immigrants. Ethnic and Racial Studies, 33(9), 1620-1647.

Kapur, D. (2010). Diaspora, development, and democracy: the domestic impact of international migration from India. Princeton: Princeton University Press.

Kibria, N. (1994). Household structure and family ideologies: The dynamics of immigrant economic adaptation among Vietnamese refugees. Social Problems, 41(1), 81-96.

Kloosterman, R., Van Der Leun, J., \& Rath, J. (1999). Mixed embeddedness: (in)formal economic activities and immigrant businesses in the Netherlands. International Journal of Urban and Regional Research, 23(2), 252-266.

Kloosterman, R., \& Rath, J. (2001). Immigrant entrepreneurs in advanced economies: mixed embeddedness further explored. Journal of Ethnic and Migration Studies, 27(2), 189-201.

Kushnirovich, N. (2015). Economic Integration of Immigrant Entrepreneurs. Entrepreneurial Business and Economics Review, 3(3), 9-27.

Langlois, A., \& Razin, E. (1995). Self-employment among French-Canadians: The role of the regional milieu. Ethnic and Racial Studies, 18(3), 581-604.

Levie, J.D., \& Smallbone, D.(2009). Immigration, ethnicity and entrepreneurial behavior. In: Perspectives on Entrepreneurship Volume 1 (pp. 157-180). Westport: Praeger Publishers.

Li, P.S. (1997). Self-employment among visible minority immigrants, white immigrants, and nativeborn persons in secondary and tertiary industries of Canada. Canadian Journal of Regional Science, 20(1), 103-118.

Lindley, A. (2009). The early-morning phonecall: Remittances from a refugee diaspora perspective. Journal of Ethnic and Migration Studies, 35(8), 1315-1334.

Minto-Coy, I.D. (2016). The Role of Diasporas in the Growth and Internationalisation of Businesses in Countries of Origin In: M. Elo \& L. Riddle (Eds.), Diaspora Business. Oxford: Interdisciplinary Press.

Mustafa, M., \& Chen, S. (2010). The strength of family networks in transnational immigrant entrepreneurship. Thunderbird International Business Review, 52(2), 97-106. 
Ohlsson, H., Broomé, P., \& Bevelander, P. (2012). Self-employment of immigrants and natives in Sweden-a multilevel analysis. Entrepreneurship \& Regional Development, 24(5-6), 405-423.

Partnership for a New American Economy (2011). The "New American" Fortune 500 (A Report by the Partnership for a New American Economy).

Pécoud, A. (2003). Self-employment and immigrants' incorporation: the case of Turks in Germany. Immigrants \& Minorities, 22(2-3), 247-261.

Portes, A., \& Zhou, M. (1993). The new second generation: Segmented assimilation and its variants. The annals of the American Academy of Political and Social Science, 530(1), 74-96.

Portes, A., Guarnizo, L. E., \& Haller, W. J. (2002). Transnational entrepreneurs: An alternative form of immigrant economic adaptation. American Sociological Review, 67(2), 278-298.

Portes, A., Guarnizo, L. E., \& Landolt, P. (1999). The study of transnationalism: pitfalls and promise of an emergent research field. Ethnic and Racial Studies, 22(2), 217-237.

Rath, J., \& Swagerman, A. (2016). Promoting Ethnic Entrepreneurship in European Cities: Sometimes Ambitious, Mostly Absent, Rarely Addressing Structural Features. International Migration, 54(1), 152-166.

Riddle, L., Hrivnak, G. A., \& Nielsen, T. M. (2010). Transnational diaspora entrepreneurship in emerging markets: Bridging institutional divides. Journal of International Management, 16(4), 398-411.

Sanders, J. M., \& Nee, V. (1996). Immigrant self-employment: The family as social capital and the value of human capital. American Sociological Review, 61(2), 231-249.

Schiller, N. G., Basch L., \& Blanc-Szanton, C. (1992). Transnationalism: A new analytic framework for understanding migration. Annals of the New York Academy of Sciences, 645, 1-24.

Smart, A., \& Hsu, J. Y. (2004). The Chinese diaspora, foreign investment and economic development in China. The Review of International Affairs, 3(4), 544-566.

Strüder, I.R. (2003). Do Concepts of Ethnic Economies Explain Existing Minority Enterprises? The Turkish Speaking Economies in London (Research Papers in Environmental and Spatial Analysis Series, 88). London: London School of Economics and Political Science.

Surdej, A., \& Wach, K. (2012). The dynamics of succession in family businesses in Poland-Empirical results. Economia Marche: Journal of Applied Economics, 31(2), 109-128.

Szarucki, M., Brzozowski, J., \& Stankevičienè, J. (2016). Determinants of self-employment among Polish and Romanian immigrants in Germany. Journal of Business Economics and Management, 17(4). 598-612.

Taylor, E. J. (1999). The new economics of labour migration and the role of remittances in the migration process. International Migration, 37(1), 63-88.

Vallejo, J. A., \& Lee, J. (2009). Brown picket fences The immigrant narrative andgiving back'among the Mexican-origin middle class. Ethnicities, 9(1), 5-31.

Vertovec, S. (2004). Migrant transnationalism and modes of transformation. International Migration Review, 38(3), 970-1001.

Volery, T. (2007). Ethnic Entrepreneurship: A Theoretical Framework. In L.P. Dana (Ed.), Handbook of Research on Ethnic Minority Entrepre-Neurship: A Co-Evolutionary View on Resource Management (pp. 30-41). Cheltenham: Edward Elgar.

Walton-Roberts, M., \& Hiebert, D. (1997). Immigration, Entrepreneurship, and the Family: IndoCanadian Enterprise in the Construction Industry of Greater Vancouver. Canadian Journal of Regional Science, XX(1,2), 119-140.

Wennekers, S., Van Wennekers, A., Thurik, R., \& Reynolds, P. (2005). Nascent entrepreneurship and the level of economic development. Small Business Economics, 24(3), 293-309. 
Wilson, K. L., \& Portes, A. (1980). Immigrant enclaves: An analysis of the labor market experiences of Cubans in Miami. American Journal of Sociology, 86(2), 295-319.

WVS (2016). World Values Survey Wave 6: 2010-2014. Vienna: Institute for Comparative Survey Research. Retrived on December 9, 2016 from:: http://www.worldvaluessurvey.org/WVSOnline.jsp

Zhou, M. (2004). Revisiting ethnic entrepreneurship: Convergences, controversies, and conceptual advancements. International Migration Review, 38(3), 1040-1074.

Zhou, M., \& Liu, H. (2015). Transnational Entrepreneurship and Immigrant Integration: New Chinese Immigrants in Singapore and the United States. In J.A. Vallejo (Ed.), Immigration and Work (Research in the Sociology of Work, Volume 27) (pp. 169-201). Bingley: Emerald Group Publishing Limited.

\section{Author}

\section{Jan Brzozowski}

Assistant Professor at the Department of European Studies, Cracow University of Economics. Member of the Committee for Migration Research of the Polish Academy of Sciences.

Correspondence to: Jan Brzozowski, PhD Assistant Professor, Department of European Studies Cracow University of Economics, Rakowicka 27, 31-510 Kraków, Poland, e-mail: jan.brzozowski@uek.krakow.pl

\section{Acknowledgements and Financial Disclosure}

The article came into being within the statutory research of the Department of European Studies financed by the Ministry of Science and Higher Education of the Republic of Poland with the funds allocated to development of research potential of the Faculty of Economics and International Relations of the Cracow University of Economics.

\section{Copyright and License}

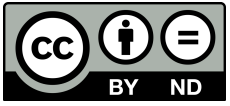

This article is published under the terms of the Creative Commons Attribution - NoDerivs (CC BY- ND 4.0) License http://creativecommons.org/licenses/by-nd/4.0/

\section{Published by the Centre for Strategic and International Entrepreneurship - Krakow, Poland}

Ministry of Science and Higher Education Republic of Poland
The copyediting and proofreading of articles in English is financed in the framework of contract No. 799/P-DUN/2017 by the Ministry of Science and Higher Education of the Republic of Poland committed to activities aimed at science promotion. 